\title{
Konfigurasi Smart TV Menggunakan Raspberry Pi Berbasis Linux Debian
}

\author{
Wahyu Ladita \\ Program Studi Teknik Informatika \\ STMIK Atma Luhur \\ Jln. Jend Sudirman - Selindung Pangkalpinang \\ ladytawahyu@gmail.com
}

\author{
Harrizki Arie Pradana \\ Program Studi Teknik Informatika \\ STMIK Atma Luhur \\ Jln. Jend Sudirman - Selindung Pangkalpinang \\ harrizkiariep@atmaluhur.ac.id
}

\begin{abstract}
Abstraksi- Penggunaan televisi yang banyak digunakan masyarakat hanya sekedar untuk menyaksikan siaran televisi, memutar video menggunakan DVD player dan bermain game menggunakan konsol game. Untuk memiliki fasilitas yang lebih banyak maka diperlukan biaya yang relatif mahal bagi masyarakat. Dengan memanfaatkan Raspberry $P i$ yang dikonfigurasikan menggunakan sistem operasi berbasis Linux debian maka dikembangkan suatu sistem yang bisa menambah fasilitas televisi layaknya smart tv pada umumnya. Metode yang digunakan dalam penelitian ini yakni perencanaan menggunakan SWOT (Strength, Weaknesses, Opportunities, Threats), analisis menggunakan Use Case dan Diagram Activity, perancangan menggunakan Flowchart, algoritma dan gambar serta implementasi yang terdapat pengujian menggunakan metode Black Box . Hasil yang didapat dalam penelitian ini yakni televisi bisa mengakses saluran televisi online yang memiliki saluran lebih banyak daripada saluran televisi lokal secara gratis, melakukan pengolahan data menggunakan aplikasi Libre Office, berbagi data melalui jaringan wireless, bermain games retro seperti Playstation serta bisa dikendalikan melaui smartphone android dalam mengakses saluran televisi online. Dalam penelitian ini tentunya internet menjadi landasan agar sistem yang dikembangkan bisa berjalan secara maksimal meskipun tidak semua fasilitas televisi dalam penelitian ini menggunakan internet. Dengan menerapkan hasil penelitian ini maka televisi sudah bisa memiliki fasilitas smart tv dengan biaya yang relatif murah.
\end{abstract}

Kata Kunci-Televisi, Raspberry Pi, Linux, Online, Smart TV

\section{Pendahuluan}

Perkembangan teknologi di era modern ini sudah tidak bisa dihindari namun harus diikuti dengan berpartisipasi dalam pengembangannya sehingga ikut merasakan dampak positifnya. Salah satunya yang sedang populer dalam pengembangannya yaitu disebut dengan istilah IoT atau internet of thing yang diketahui sebagai suatu konsep yang bertujuan untuk memperluas manfaat dari konektivitas internet yang tersambung secara terus-menerus atau bisa disimpulkan menjadi segala benda yang berhubungan langsung dengan internet mulai dari benda fisik maupun virtual melalui pemanfaatan data dan kemampuan komunikasi. Salah satu pengembangan IoT yang cukup populer yaitu dikenal dengan istilah smart tv, yaitu suatu konsep menggunakan media televisi yang bisa mengakses langsung ke internet. Dengan terhubungnya ke internet langsung maka memungkinkan pengguna untuk mengakses saluran televisi online yang mempunyai banyak saluran di seluruh dunia dan juga bisa mengakses video online seperti Youtube dan lain-lain sehingga bisa mendapatkan lebih banyak informasi dibandingkan saluran televisi lokal.

Sebagai media informasi tentunya sudah diketahui bahwa televisi merupakan salah satu pemegang peran yang sangat penting dalam kemajuan penyebaran informasi, media pmbelajaran, hiburan dan lain-lain. Dengan semakin meningkatnya kebutuhan masyarakat akan informasi yang luas, beragam dan menarik, maka banyak pula teknologi informasi terbaru yang berusaha untuk memenuhi kebutuhan tersebut. Internet sudah menjadi sarana umum yang digunakan untuk menghubungkan seluruh dunia menjadi satu kesatuan informasi serta menjadi landasan dalam pengembangan teknologi informasi pada masa sekarang ini. Pemanfaatan televisi bukan hanya untuk menyaksikan siaran televisi, memutar video meggunakan DVD player, dan bermain games saja seperti yang pada umumya digunakan masyarakat, namun sudah bisa multitasking seperti melakukan aktivitas pengolahan data layaknya komputer, berbagi data melalui jaringan wireless, berselancar di internet, bisa dikendalikan melalui smart-phone dan lain-lain. Untuk mendapatkan fasilitas tersebut pada televisi maka diperlukan biaya yang relatif mahal. Dengan mengetahui latar belakang masalah tersebut maka dikembangkan suatu sistem yang berkonsep smart tv dengan memanfaatkan Raspberry Pi sebagai media pengolah sistem operasi berbasis Linux debian yang dipasang pada MicroSD sebagai penyimpanan utama file system pada Raspberry Pi sehingga bisa menambah fasilitas televisi seperti mengakses saluran televisi online, melakukan aktivitas pengolahan data layaknya komputer menggunakan aplikasi office berbasis Linux, berbagi data menggunakan jaringan wireless, bermain games, serta bisa dikendalikan menggunakan smart-phone dalam navigasi akses saluran televisi online. 


\section{Metode Penelitian}

Metode penelitian yang digunakan yaitu perencanaan, analisis, perancangan serta implementasi. Perencanaan dalam penelitian ini terbagi menjadi dua yakni studi literatur dengan mencari referensi teori yang berhubungan dengan permasalahan dalam penelitian ini dan studi kelayakan menggunakan metode analisis SWOT (Strength, Weaknesses, Opportunities, Threats) yang bertujuan untuk menganalisa bahwa sistem yang dikembangkan layak untuk digunakan. Analisis merupakan tahap menganalisa suatu sistem berdasarkan pada sistem yang sedang terjadi dan sistem yang diusulkan Analisis yang digunakan dalam penelitian ini yakni analisis sistem berjalan yang dijelaskan menggunakan use case dan diagram activity dan analisis sistem usulan berupa analisis perangkat lunak dan analisis perangkat keras. Perancangan merupakan tahap merancang input, proses, dan output yang dirancang menggunakan flowchart dan algoritma serta model usulan yang dirancang menggunakan gambar. Implementasi berguna untuk menerapkan hasil analisis dan perancangan dengan melakukan pemasangan terhadap hardware dan software yang dibutuhkan serta melakukan pengujian terhadap sistem yang telah di kembangkan menggunakan metode pengujian black box sehingga bisa berjalan secara maksimal sesuai yang diharapkan.

\section{PembahasAn}

Pembahasan yang dilakukan dalam penelitian ini meliputi perencanaan, analisis, perancangan dan implementasi yang bertujuan untuk mengetahui bahwa sistem bisa berjalan sesuai yang diinginkan.

\section{A. Perencanaan}

Perencanaan merupakan tahap awal yang dilakukan sebelum melakukan tahap analisis, perancangan dan implementasi. Tahap perencanaan menggunakan metode analisis SWOT yang bertujuan untuk menganalisa bahwa Konfigurasi Smart TV Menggunakan Raspberry Pi Berbasis Linux Debian bisa menambah fasilitas televisi yang banyak digunakan oleh masyarakat. Berikut ini merupakan analisis SWOT pada Konfigurasi Smart TV Menggunakan Raspberry Pi Berbasis Linux Debian yang dijelaskan pada Tabel 1.

Tabel 1. Analisis SWOT

\begin{tabular}{|c|c|}
\hline & $\begin{array}{l}\text { 1. Menambah fungsi dari } \\
\text { televisi untuk bisa menjadi } \\
\text { PC (Personal Computer). } \\
\text { 2. Harga perangkat relatif } \\
\text { murah }\end{array}$ \\
& $\begin{array}{l}\text { 3. Terintegrasi perangkat lain } \\
\text { seperti dalam hal bertukar } \\
\text { data melalui smart-phone }\end{array}$ \\
4. Pengendalian pada akses \\
televisi online bisa \\
menggunakan smart- \\
phone Android
\end{tabular}

\begin{tabular}{|c|c|}
\hline & \multicolumn{1}{|c|}{$\begin{array}{c}\text { internet dalam mengakses } \\
\text { saluran televisi online. }\end{array}$} \\
\hline Opportunities & $\begin{array}{l}\text { 1. Alat ini dapat menambah } \\
\text { fasilitas televisi } \\
\text { 2. Merupakan inovasi baru } \\
\text { karena masih jarang } \\
\text { digunakan. } \\
\text { 3. Bisa dikembangkan sesuai } \\
\text { kebutuhan penggunannya. }\end{array}$ \\
\hline Threats & $\begin{array}{l}\text { 1. Gangguan jaringan } \\
\text { internet yang bisa } \\
\text { mengakibatkan putusnya } \\
\text { koneksi internet. } \\
\text { Benturan pada alat yang } \\
\text { mengakibatkan rusaknya } \\
\text { komponen. }\end{array}$ \\
\hline
\end{tabular}

Dari analisis SWOT pada Tabel 1 didapatkan strategi yang direncanakan. Berikut ini merupakan penerapan strategi SWOT yang dijelaskan pada Tabel 2.

Tabel 2. Penerapan Strategi SWOT

\begin{tabular}{|c|c|}
\hline Strategi S-O & $\begin{array}{l}\text { 1. } \begin{array}{l}\text { Harga perangkat yang } \\
\text { relatif murah } \\
\text { mengurangi } \\
\text { beban } \\
\text { masyarakat } \\
\text { memiliki fasilitas smart }\end{array} \\
\text { tv. } \\
\text { 2. Terintegrasinya antara } \\
\text { televisi dengan perangkat } \\
\text { lain dapat menjadikan } \\
\text { fleksibelnya fungsi dari } \\
\text { televisi. }\end{array}$ \\
\hline Strategi W-O & $\begin{array}{l}\text { 1. Konfigurasi Smart TV } \\
\text { Menggunakan Raspberry } \\
\text { Pi Berbasis Linux Debian } \\
\text { dalam penelitian ini } \\
\text { ditujukan kepada } \\
\text { pengguna yang memiliki } \\
\text { televisi dan jaringan } \\
\text { internet namun belum } \\
\text { diintegrasikan fungsi dari } \\
\text { keduanya. } \\
\text { 2. Konfigurasi smart tv } \\
\text { dalam penelitian ini } \\
\text { ditujukan bagi pangguna } \\
\text { yang memiliki televisi } \\
\text { dan ingin memiliki PC } \\
\text { (Personal Computer) } \\
\text { namun memiliki } \\
\text { keterbatasan biaya. }\end{array}$ \\
\hline Strategi S-T & 1. Alat menggunakan case \\
\hline
\end{tabular}




\begin{tabular}{|c|c|}
\hline & $\begin{array}{l}\text { untuk mencegah } \\
\text { benturan. }\end{array}$ \\
\hline Strategi W-T & $\begin{array}{l}\text { 1. Untuk mengatasi masalah } \\
\text { Konfigurasi smart tv } \\
\text { menggunakan Raspberry } \\
\text { Pi berbasis Linux debian } \\
\text { terhadap benturan yang } \\
\text { mengakibatkan kerusakan } \\
\text { komponen, perangkat } \\
\text { dipasangkan hardcase } \\
\text { yang bisa melindungi } \\
\text { perangkat. } \\
\text { 2. Untuk mengatasi masalah } \\
\text { gangguan jaringan } \\
\text { internet, bisa } \\
\text { menggunakan jaringan } \\
\text { IndieHome Fiber Optic. }\end{array}$ \\
\hline
\end{tabular}

\section{B. Analisis}

\section{1) Analisis Sistem Berjalan}

Dalam sistem smart tv sekarang masih digunakan pada televisi yang relatif tergolong mahal karena fasilitasnya yang masih jarang digunakan oleh televisi kebanyakan sehingga perlu dikembangkan sistem yang bisa mengatasi masalah tersebut. Dengan menggunakan metode penelitian yang digunakan maka penggambaran atau pemodelan sistem yang sedang berajalan saat ini yaitu proses alur kerja sistem smart tv akan direpresentasikan menggunakan notasi UML, yaitu Use Case diagram dan Actvity diagram. Berikut ini merupakan Use Case pada analisa sistem berjalan yang dijelaskan pada Gambar 1 .

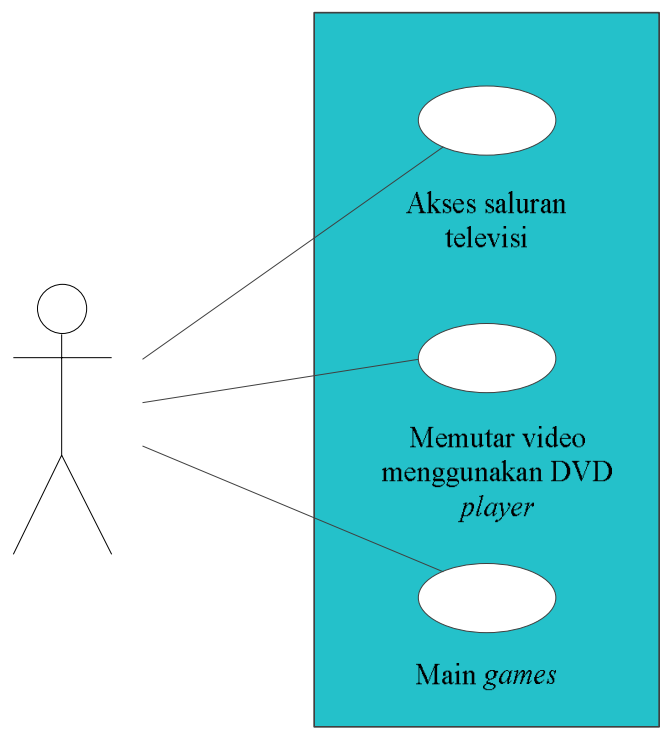

Gambar 1. Use Case Analisa sistem berjalan

Berikut ini merupakan Activity diagram pada analisis sistem berjalan yang dijelaskan pada Gambar 2, Gambar 3 dan Gambar 4.

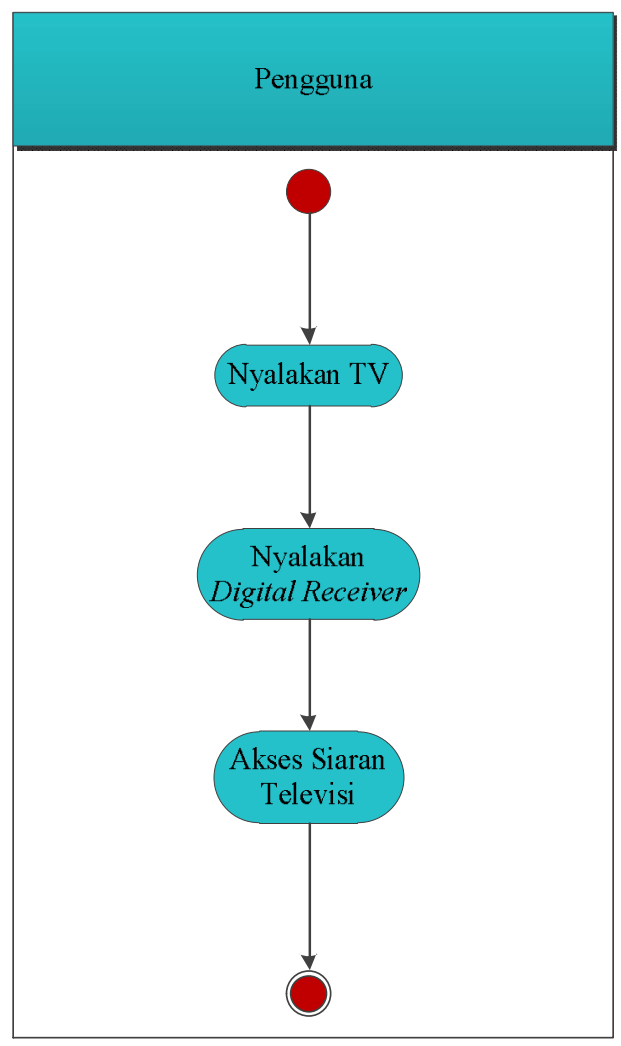

Gambar 2 Activity diagram proses Akses saluran televisi 


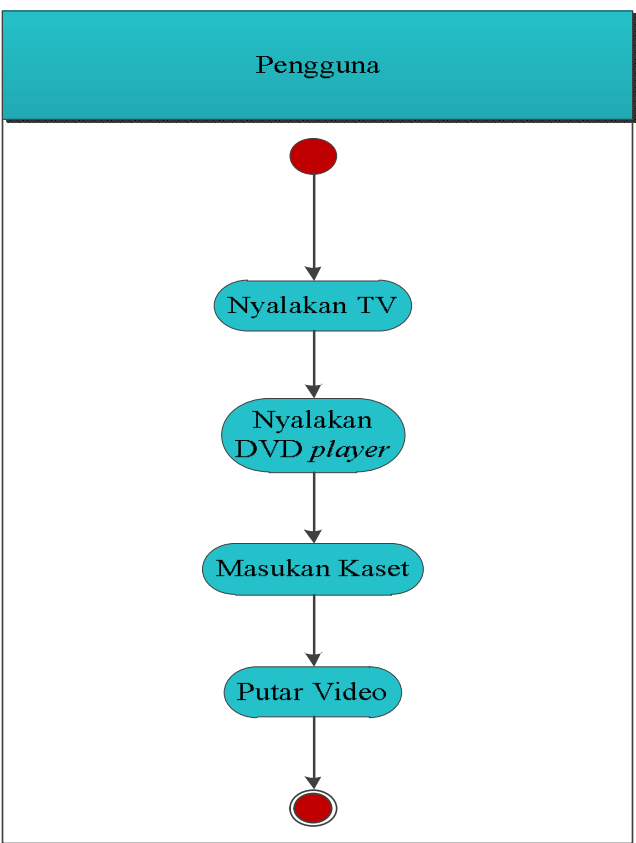

Gambar 3. Activty diagram proses memutar video pada televisi

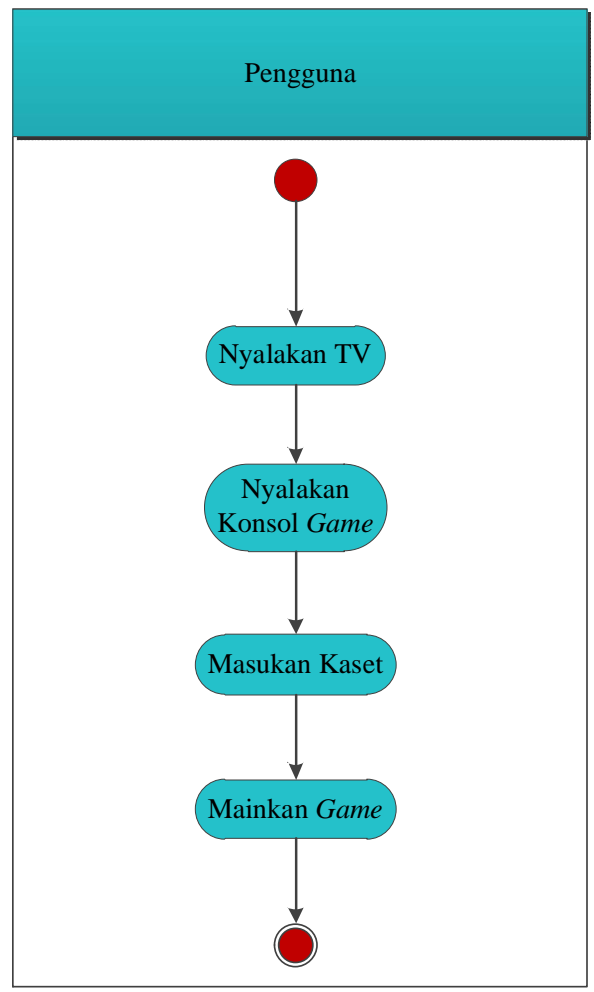

Gambar 4. Activity diagram proses memainkan games pada televisi

\section{2) Analisis Sistem Usulan}

Analisis sistem usulan yang diperlukan dan yang digunakan dalam pengembangan sistem smart tv menggunakan Raspberry Pi berbasis Linux debian ini terdiri dari beberapa bagian, yaitu analisis perangkat lunak dan analisis perangkat keras. Berikut ini merupakan analisis perangkat lunak pada Konfigurasi Smart TV Menggunakan Raspberry Pi Berbasis Linux Debian:

\section{3) Perangkat Lunak}

a) Rasbian Jessie

Raspbian Jessie merupakan sistem operasi hasil pengembangan Debian Jessie 8.0 khusus untuk Raspberry $\mathrm{Pi}$ yang digunakan untuk menjalankan semua fungsi dari sistem smart tv menggunakan Raspberry Pi.

b) Kodi

Kodi atau yang dulu dikenal dengan XBMC (Xbox Media Center) versi 15.2 yang digunakan merupakan aplikasi media center yang berfungsi untuk mengakses saluran televisi online.

c) Bluetooth

Bluetooth digunakan untuk berbagi data melalui jaringan wireless

d) RetroPie

RetroPie merupakan aplikasi yang berfungsi sebagai emulator berbagai game console untuk Raspberry Pi seperti, PSX, Sega, GameBoyAdvance, Nintendo dan lain-lain.

e) Yatse

Yatse merupakan aplikasi Android yang berfungsi sebagai remote control untuk smart tv menggunakan Raspberry Pi pada smart-phone Android.

\section{4) Perangkat Keras}

a) Laptop

Laptop digunakan untuk proses instalasi sistem operasi Raspbian pada kartu MicroSD.

\section{b) Televisi}

Televisi digunakan untuk menampilkan proses yang terjadi dalam hasil pengolahan pada Raspberry Pi.

c) Keyboard

Keyboard digunakan untuk mengetikan perintah yang diperlukan atau kode program.

d) Mouse

Mouse digunakan juga untuk bernavigasi dalam proses navigasi pada Raspberry $\mathrm{Pi}$ untuk pengembangan sistem.

e) Raspberry Pi 2 Model B

Raspberry Pi digunakan untuk menjalankan sistem smart tv pada peneletian ini.

\section{f) $U S B W i-F i$}

USB Wi-Fi digunakan sebagai interface network adapter pada Raspberry $\mathrm{Pi}$ yang berfungsi untuk menangkap sinyal Wi-Fi yang tersedia.

g) Kabel Audio ke RCA 
Kabel Audio ke RCA digunakan untuk menghubungkan Raspberry Pi ke televisi.

h) Kabel HDMI

Kabel HDMI digunakan untuk menghubungkan Raspberry $\mathrm{Pi}$ ke televisi dengan tampilan high definition.

\section{i) Adaptor Power Supply}

Adaptor digunakan untuk memberikan daya pada Raspberry Pi dengan menghubungkan arus listrik ke Raspberry Pi.

j) Raspberry Pi 2 Case

Case digunakan untuk melindungi Raspberry Pi dari gannguan luar dan mencegah pengguna terkena arus listrik pada Raspberry Pi.

\section{k) Card Reader}

Card Reader digunakan untuk proses burning sistem operasi ke MicroSD menggunakan laptop melalui USB port.

l) MicroSD

MicroSD digunakan untuk menyimpan file system dari sistem operasi Raspbian. Pada penelitian ini menggunakan SandDisk Ultra 32GB class 10.

\section{m)Smart-phone Android}

Smart-phone Android digunakan remote control atau pengendali yang terhubung melalui jaringan internet ke Raspberry Pi.

\section{n) Bluetooth dongle}

Bluetooth dongle digunakan untuk berbagi data ke televisi melalui jaringan wireless

o) Gamepad

Gamepad digunakan sebagai pengganti keyboard dan mouse dalam bermain games RetroPie sehingga lebih efektif dalam bermain games.

\section{p) USB Hub (Optional)}

USB Hub digunakan untuk menambahkan port USB pada Raspberry Pi. Pada penelitian ini jumlah port USB yang ditamabahkan sebanyak 4 port USB 3.0.

\section{Perancangan}

Perancangan merupakan proses yang menjelaskan tahapan dalam proses yang terjadi pada pengembangan smart tv menggunakan Raspberry $\mathrm{Pi}$, tahapan ini adalah tahapan lanjutan setelah proses analisis yang dilakukan sebelumnya, selain itu juga dalam tahapan ini perancangan dibuat untuk mempersiapkan proses implementasi, dan untuk menggambarkan proses-proses yang terjadi sebelum implementasi.

\section{1) Deployment Diagram}

Berikut adalah deployment diagram Konfigurasi smart tv menggunakan Raspberry Pi berbasis Linux debian yang dijelaskan pada Gambar 5.

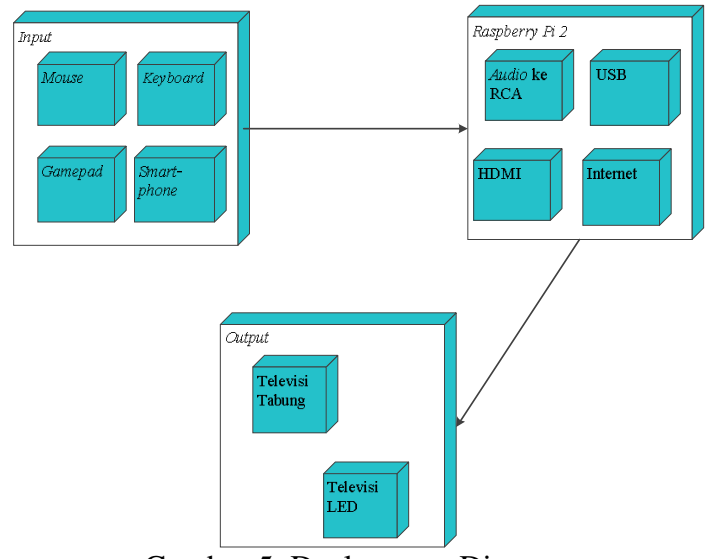

Gambar 5. Deployment Diagram

Diagram pada Gambar 5 menjelaskan bahwa semua komponen perangkat keras (hardware) saling berhubungan pada perancangan smart tv menggunakan Raspberry Pi. Proses input menggunakan mouse, keyboard dan gamepad yang terhubung melalui port USB yeng tersedia pada Raspberry Pi dan smart-phone yang terhubung melalui internet yang selanjutnya akan diproses oleh Raspberry Pi dan diteruskan ke televisi tabung menggunakan media kabel Audio ke RCA sedangkan televisi LED dihubungkan menggunakan HDMI yang bertujuan sebagai interface.

\section{2) Component Diagram}

Berikut ini merupakan component diagram dari Konfigurasi smart tv menggunakan Raspberry Pi berbasis Linux debian yang dijelaskan pada Gambar 6.

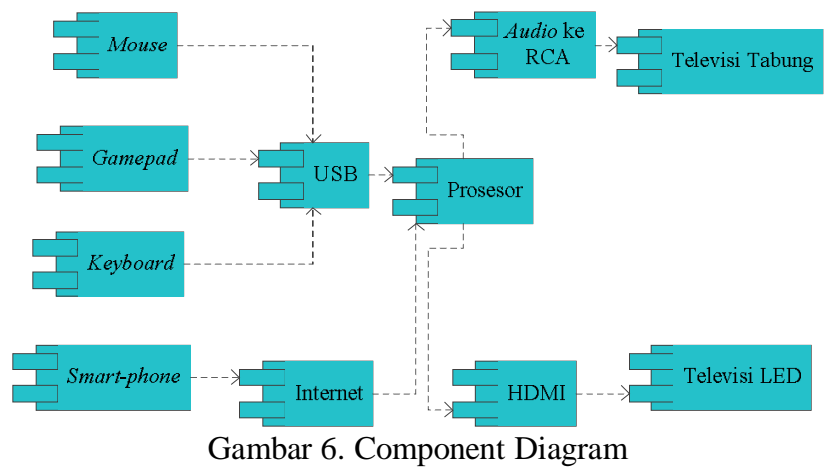

Diagram komponen yang pada Gambar 6 dapat dilihat bahwa proses yang terjadi berawal dari proses masukan melalui alat masukan yakni mouse, keyboard, gamepad dan smart-phone yang tersedia dan selanjutnya akan diproses oleh Prosesor. Kemudian akan diteruskan ke media televisi tabung yang dihubungkan menggunakan kabel Audio ke RCA sedangkan untuk televisi LED dihubungkan menggunakan HDMI sebagai interface. Untuk penggunaan televisi harus dilakukan secara terpisah dengan memilih salah satunya.

Berikut ini merupakan perancangan ouput keseluruhan yang dijelaskan pada Gambar 7. 


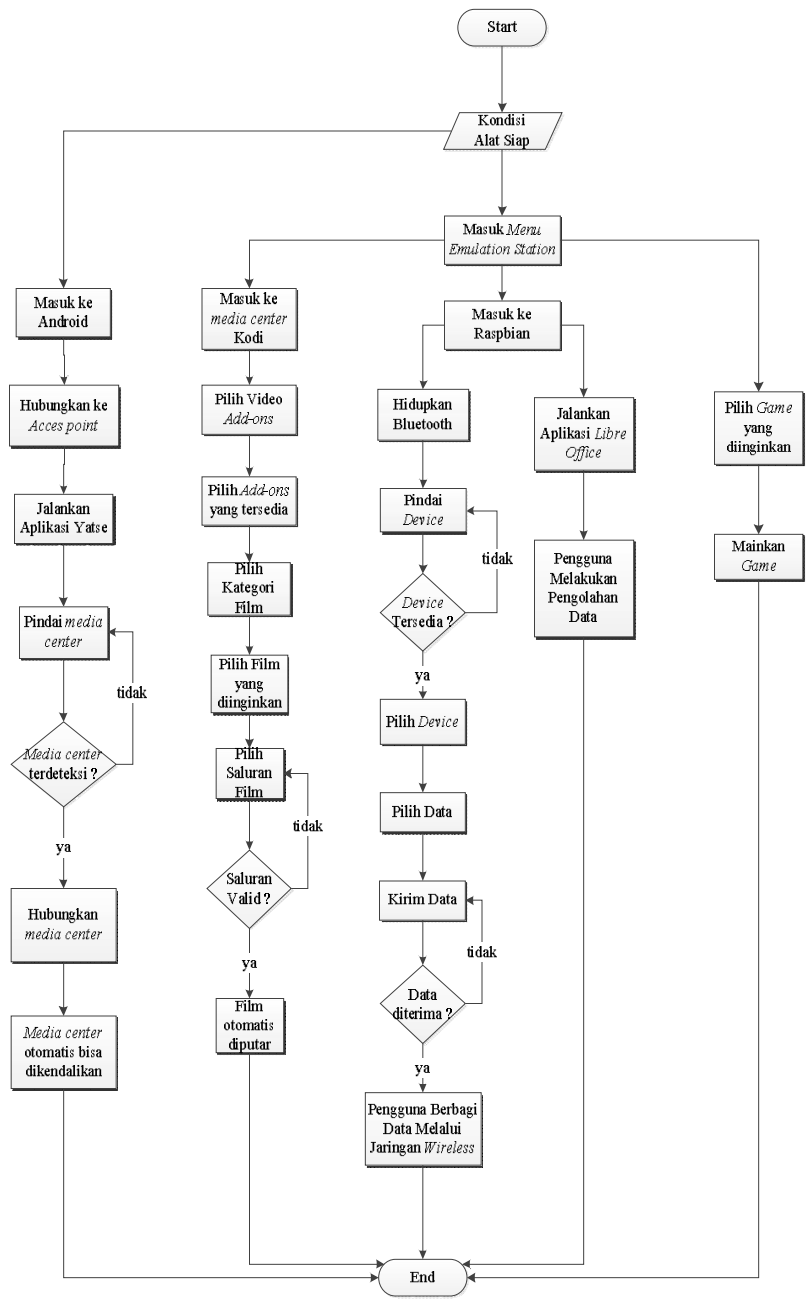

Gambar 7. Flowchart perancangan output

Didalam perancangan terdapat perancangan input, proses dan output. Pada Gambar 7 dijelaskan merupakan hasil keseluruhan dari perancangan input dan proses.

Berikut ini perancangan model usulan terhadap sistem yang dirancang yang dijelaskan pada Gambar 8.

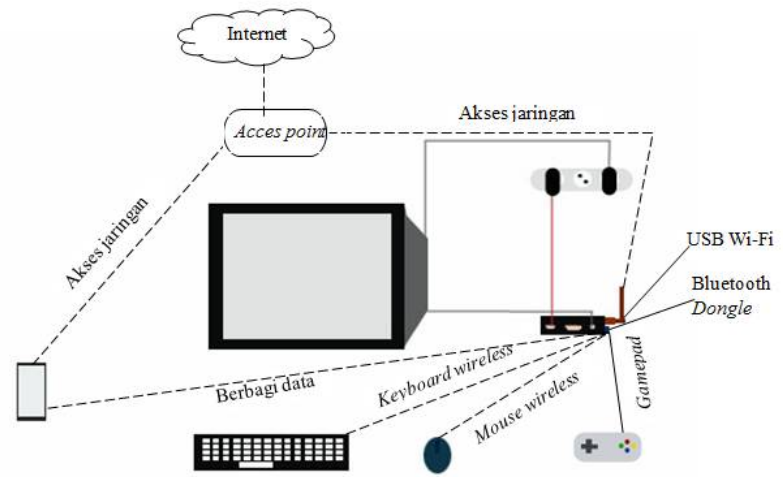

Gambar 8. Perancangan model usulan

\section{IMPLEMENTASI}

Dalam proses implementasi terdapat 3 proses yakni instalasi perangkat lunak, instalasi perangkat keras dan pengujian. Pada proses instalasi perangkat lunak terdapat tahapan seperti berikut ini:

- Instalasi sistem operasi Raspbian menggunakan software SDFormatter dan Win32DiskImager.

- Instalasi aplikasi Kodi yang merupakan aplikasi media center yang berguna dalam proses akses saluran televisi online.

- Instalasi Bluetooth yang merupakan sarana dalam proses berbagi data melalui jaringan wireless.

- Instalasi aplikasi RetroPie yang berfungsi sebagai emulator sistem game yang akan digunakan serta menjadi menu utama ketika masuk ke sistem yang befungsi menghubungkan sistem GUI, aplikasi Kodi dan game center menjadi lebih efisien.

- Instalasi remote control smar $\neg$ t-phone android menggunakan aplikasi Yatse.

Pada proses instalasi perangkat keras terdapat tahapan sebagai berikut.

- Untuk penggunaan kabel RCA terdapat proses menyambungkan kabel ground dan positif secara terbalik pada kabel warna merah dan putih.

- $\quad$ Pasang Wi-Fi dongle, USB wireless, Bluetooth dongle serta gamepad pada Raspberry Pi.

- $\quad$ Pasang kabel adaptor dan RCA atau HDMI.

Dalam proses pengujian menggunakan metode pengujian black box yang dijelaskan pada Tabel 3 .

Tabel 3. Proses Pengujian

\begin{tabular}{|c|l|l|c|}
\hline Id & \multicolumn{1}{|c|}{$\begin{array}{c}\text { Prosedur } \\
\text { Pengujian }\end{array}$} & $\begin{array}{c}\text { Hasil yang } \\
\text { didapat }\end{array}$ & Validasi \\
\hline 1 & $\begin{array}{l}\text { Akses media } \\
\text { center melalui } \\
\text { aplikasi Kodi }\end{array}$ & $\begin{array}{l}\text { Pengguna } \\
\text { dapat } \\
\text { mengakses } \\
\text { saluran } \\
\text { televisi, video } \\
\text { dan musik } \\
\text { secara online. }\end{array}$ & Valid \\
\hline 2 & $\begin{array}{l}\text { Melakukan } \\
\text { pengolahan } \\
\text { data }\end{array}$ & $\begin{array}{l}\text { Penguna dapat } \\
\text { melakukan } \\
\text { aktivitas } \\
\text { pengolahan } \\
\text { data. }\end{array}$ & Valid \\
\hline 3 & $\begin{array}{l}\text { Bermain } \\
\text { games } \\
\text { RetroPie }\end{array}$ & $\begin{array}{l}\text { Pengguna } \\
\text { dapat } \\
\text { memainkan } \\
\text { games }\end{array}$ & Valid \\
\hline
\end{tabular}




\begin{tabular}{|c|l|l|l|}
\hline & & $\begin{array}{l}\text { RetroPie } \\
\text { menggunakan } \\
\text { Gamepad. }\end{array}$ & \\
\hline 4 & $\begin{array}{l}\text { Mengendalikan } \\
\text { aplikasi Kodi } \\
\text { menggunakan } \\
\text { Smart-phone } \\
\text { Android }\end{array}$ & $\begin{array}{l}\text { Pengguna } \\
\text { dapat } \\
\text { mengendalikan } \\
\text { media center } \\
\text { menggunakan } \\
\text { smart-phone } \\
\text { Android } \\
\text { sebagai basis } \\
\text { remote control. }\end{array}$ & Valid \\
\hline 5 & $\begin{array}{l}\text { Berbagi data } \\
\text { menggunakan } \\
\text { jaringan } \\
\text { wireless }\end{array}$ & $\begin{array}{l}\text { Pengguna } \\
\text { dapat berbagi } \\
\text { data berupa } \\
\text { file video, } \\
\text { dokumen dan } \\
\text { lain-lain. }\end{array}$ & Valid \\
\hline
\end{tabular}

\section{KeSIMPULAN}

Berdasarkan analisis penulis dalam penelitian ini bahwa fungsi televisi bisa sangat produktif dalam membantu melakukan pekerjaan sehari-hari adapun fungsi televisi yang bisa didapatkan pada penelitian ini yaitu:

- Sebagai media untuk melakukan pengolahan data layaknya komputer pada umumnya, dalam hal ini televisi bisa melakukan pengolahan data seperti dokumen, slide, dan perhitungan.
- Sebagai game center, dalam hal ini televisi bisa menjadi media dalam bermain konsol game.

- Sebagai media center, dalam hal ini televisi dapat dijadikan media untuk akses saluran televisi online melalui jaringan internet.

- Sebagai media untuk berbagi data melalui jaringan wireless, dalam hal ini televisi menggunakan Bluetooth untuk berbagi data.

Selain itu juga pengontrolan televisi menggunakan smartphone Android juga bisa dilakukan sebagai media pengganti remote control pada televisi walaupun remote control khusus juga tersedia namun pada era sekarang smart-phone lebih sering digunakan dalam beraktivitas sehingga lebih memudahkan.

\section{DAFTAR PUSTAKA}

[1] Norris, Donald, "Raspberry Pi Project for the Evil Genius," United States: McGraw-Hill Education, 2013.

[2] Fajrillah, "Sistem Operasi Komputer: Dilengkapi dengan Studi Kasus Sistem Operasi DOS, Windows, Macintosh, dan Linux" Bogor: Ghalia Indonesia, 2011.

[3] Monk, Simon, "Raspberry Pi Cook Book". United States: O'Reilly, 2014.

[4] Horan, Brendan, "Practical Raspberry Pi", New York: Apress, 2013.

[5] Hague, Andrew et al "“ The Raspberry Pi Education Manual," Tersedia di:

[6] http://pi.cs.man.ac.uk/download/Raspberry_Pi_Education_Manu al.pdf 